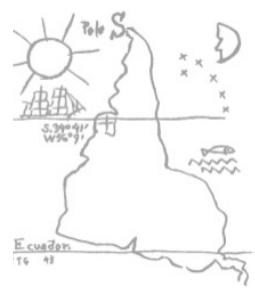

\title{
ALTERNAUTAS
}

Vol.5 - Issue 2 [December 2018]

Oscar Webber

\section{The Plantation's role in enhancing hurricane vulnerability in the nineteenth-century British Caribbean}

Alternautas is a peer reviewed academic journal that publishes content related to Latin American Critical Development Thinking.

It intends to serve as a platform for testing, circulating, and debating new ideas and reflections on these topics, expanding beyond the geographical, cultural and linguistic boundaries of Latin America - Abya Yala. We hope to contribute to connecting ideas, and to provide a space for intellectual exchange and discussion for a nascent academic community of scholars, devoted to counterbalancing mainstream understandings of development.

How to cite:

Webber Oscar. (2018), The Plantation's role in enhancing hurricane vulnerability in the nineteenth-century British Caribbean. Alternautas, 5(2), 2942. URL:

http://www.alternautas.net/blog/2018/9/20/the-plantations-role-inenhancing-hurricane-vulnerability-in-the-nineteenth-century-british-caribbean

Editor : Alternautas

http://www.alternautas.net

London, UK.

ISSN - 2057-4924 


\section{The Plantation's role in enhancing hurricane vulnerability in the nineteenth-century British Caribbean ${ }^{2}$}

Hurricanes are the hazard most synonymous with the Caribbean. Reflecting that, they have received the most attention from historians. ${ }^{3}$ Yet, they have tended to consider them like historians have traditionally treated disaster; as a mostly exogenous phenomena. There has been little attention paid to the role endogenous factors have played in exacerbating the potential for loss from hurricane impacts. ${ }^{4}$ Disasters arise when people are made vulnerable to the impacts of natural phenomena; this vulnerability is constructed over time and because of this, historians, with their

\footnotetext{
' OSCAR WEBBER is an environmental historian whose research focuses on human responses to nature-induced disasters. Though they have received little attention from historians, disasters are the product of historical processes and, as such, are ripe for historical investigation. He is specifically interested in exploring the processes of, and motivations behind, relief and aid giving.

2 This article was originally published in http://www.alternautas.net/blog/2018/9/20/theplantations-role-in-enhancing-hurricane-vulnerability-in-the-nineteenth-century-britishcaribbean on September 20th, 2018.

3 Matthew Mulcahy, Hurricanes and Society in the British Greater Caribbean, 1624-1783 (Baltimore: Johns Hopkins University Press, 2006); Stuart Schwartz, Sea of Storms: A History of Hurricanes in the Greater Caribbean from Columbus to Katrina (Princeton: Princeton University Press, 2015).

${ }^{4}$ S. D. Smith, 'Storm Hazard and Slavery: The Impact of the 1831 Great Caribbean Hurricane on St Vincent', Environment and History, 18.1 (2012), p. 100; the United Nation's strategy for disaster reduction defines vulnerability as 'as the potential for loss (human, physical, economic, natural, or social) due to a hazardous event'. United Nations International Strategy for Disaster Reduction, UNISDR terminology on disaster risk reduction (Geneva, 2009).
} $* *$ 
temporal expertise, are uniquely suited to uncover its historic roots. ${ }^{5}$ Through a comparison of the impacts of the Barbadian hurricane of 1831 and the Dominican hurricane of 1834 this article seeks to advance the existing literature by examining the role the plantation played in exacerbating hurricane vulnerability. In revealing the significantly contrasting amount of damage these islands sustained, this article shows that, at least in this case, the more expansive plantation agriculture of Barbados exposed its habitants to far greater human, economic and environmental losses.

Through the system of slavery that built and worked the plantations, stark racial bifurcation became the fundamental pillar on which British Caribbean society was built. Historians of the British Caribbean have repeatedly shown that this system created severe material inequalities that made the African-Caribbean population vulnerable in other ways. ${ }^{6}$ However, because an examination of the role played by the plantation agriculture in enhancing hurricane vulnerability has remained unexamined it is the central focus of this article. Historical geographers such as Bonham Richardson have examined the environmental devastation that plantation agriculture wrought upon the Caribbean environment. ${ }^{7}$ However, it is the implications of that devastation (in the form of deforestation, soil erosion and the marginalisation of subsistence crops) in the context of nature-induced hazards has been little examined. ${ }^{8}$

Hurricanes are always accompanied by rain and strong winds which present obvious dangers to human life, but they can also trigger epiphenomenal hazards such as landslips and soil liquefaction that increase the potential for loss. The occurrence of

\footnotetext{
${ }^{5}$ Greg Bankoff, 'Time is of the Essence: Disasters, Vulnerability and History', International Journal of Mass Emergencies and Disasters, 22:3 (2004), pp.23-42.

${ }^{6}$ B. W. Higman, Slave Populations of the British Caribbean, 1807-1834 (Kingston: University of the West Indies Press, 1995).

7 Bonham C. Richardson, The Caribbean in the Wider World, 1492-1992: A Regional Geography (Cambridge, England: Cambridge University Press, 1992).

${ }^{8}$ B.W. Higman, Slave Populations of the British Caribbean, 1807-1834, p. 214. **
} 
such epiphenomenal hazards in the wake of hurricanes was common throughout the Caribbean. In his history of Barbados, Robert Schomburgk relates that enormously destructive landslides always followed hurricane rains. ${ }^{9}$ What is particularly interesting is that throughout the region, the most severe landslides appear to have occurred following hurricane impacts on islands or parts of islands where plantation agriculture was most extensive. On Jamaica in 1815 for example, severe landslides took place directly on the sugar plantations. ${ }^{10}$ Witnesses describe effects that appear representative of severe soil liquefaction; the ground on plantations 'broke' and swallowed buildings so quickly that they 'threatened to bury' their inhabitants. ${ }^{11}$

The answer to why such epiphenomenal hazards were particularly common in the Caribbean lies in understanding how sugar plantations expanded in the region. Sugar requires open, level land and consequently, the creation of plantations throughout the British Caribbean began a process of land clearance and deforestation. Trees and their roots however play a key role in soil cohesion. On islands such as Barbados which was almost entirely deforested by the 1660s, contemporary observers soon saw a link emerging between the plantation and the prevalence of landslips. Naturalist Griffith Hughes observed that especially where large amounts of sugar cane were planted, the soil 'often [ran] away' and moved with 'violence' often 'tumbling down' in the face of the first period of extended rain it faced. ${ }^{12}$

The frequency of landslips meant planters built walls and weirs around their plantation to limit soil runoff. They did not however, attempt to limit the expansion

\footnotetext{
9 Sir Robert Hermann Schomburgk, The History of Barbados: Comprising a Geographical and Statistical Description of the Island, a Sketch of the Historical Events Since the Settlement, and an Account of Its Geology and Natural Productions (Frank Cass, 1848), p. 67-68.

$10 \mathrm{lbid}, \mathrm{p} .106$.

11 'The Late Hurricane in Jamaica: with reflections', Baptist Magazine, October 31, 1815, p.106.

${ }^{12}$ Griffith Hughes, The Natural History of Barbados In Ten Books. (London: Printed for the author, 1750), pp.2O-22.
}

** 
of plantations nor the intensity with which they were farmed. ${ }^{13}$ There were individuals who not only saw the damage created by the plantation but even went as far as to link it directly to the actions of the planters. Alexander Anderson is his 1799 book Geography and History of St. Vincent expressed frustration about deforestation and sought to highlight the role it played screening the land (one assumes from storms). ${ }^{14}$ On St. Vincent laws were passed to prevent the clearing away of woods at the sources of the island's rivers that fed estates and ports, presumably so that their flow was not interrupted. ${ }^{15}$ These changes appear as exceptions however; by the nineteenth century, plantation agriculture had intensified to the extent that on islands such as Barbados Richard Madden observed that were it not for the application of seaweed to the island's soils, nothing would grow at all. ${ }^{16}$

It is in an anonymous eyewitness' account of the Barbadian hurricane of 1831 titled the Account of the Fatal Hurricane that provides the first indication that the hurricane triggered the aforementioned epiphenomenal hazards such as soil liquefaction and landslides. ${ }^{17}$ In 1831 one day after the hurricane, the author of Account described the state of Barbados: 'no sign of vegetation was apparent...the surface of the ground appeared as if fire had ran through the land'. ${ }^{18}$ Other eye witnesses reported seeing the hurricane-borne deluge of rain opening huge chasms in the ground which swallowed their livestock whole. ${ }^{19}$ The phenomenon of landslips that these accounts all note are not simply a natural part of the Caribbean environment, at least not on

${ }^{13}$ David Watts, The West Indies: Patterns of Development, Culture and Environmental Change Since 1492 (Cambridge University Press, 1990), p. 397.

14 Ibid, p. 163.

${ }^{15}$ London. The National Archives, $\mathrm{CO}$ 263/4 (St. Vincent) Legislative Council; Privy Council, 'An Act to Prevent the clearing away of wood at the fountainheads of rivers running to any town or shipping place in this island or that supply estates with water', December 3, 1811.

${ }^{16}$ Richard Robert Madden, A Twelvemonth's Residence in the West Indies, during the Transition from Slavery to Apprenticeship; with Incidental Notice of the State of Society, Prospects, and Natural Resources of Jamaica and Other Islands (Philadelphia, Carey, Lea and Blanchard, 1835),

p. 35.

17 Editor of the 'West Indian', Account of the Fatal Hurricane by Which Barbados Suffered in August 1831 (Barbados: Printed for Samuel Hyde, 1831), p. 1-28.

${ }^{18}$ Editor of the 'West Indian', p. 47.

19 Ibid, p. 23. 
the scale noted in these sources. Indeed, Hughes discusses the phenomena of landslips on Barbados because he felt it would surprise those unacquainted with the island, the inference being that he knew that for his European readers there was little they could compare them to. Here what we are seeing is one of a number of the disastrous side effects of plantation agriculture that became evident after the hurricane.

The evidence provided by eyewitness accounts of the Barbadian hurricane of 1831 shows a level of epiphenomenal catastrophe not experienced on other islands. The hurricane that struck Dominica in 1834 gives us a case that works, albeit not perfectly, as a nonetheless useful analogue by which to illustrate to some degree the effects that sugar plantations and the mass deforestation they occasioned had on exacerbating vulnerability to hurricanes. Of the ways in which Dominica differed from Barbados in the 1830s, what is most crucial for the purposes of this article is their differing agricultural configurations. Where Barbados very obviously focused on the cultivation of sugar, Dominica differentiated and instead focused on coffee. In his visit to Dominica, Joseph Sturge found that cane on Dominica was actually regarded as growing too 'rank and luxuriantly for the full secretion and maturation of its saccharine juices, so that it is less productive than in the dry, exhausted soils of Antigua and Barbados'. ${ }^{20}$

Though the growth of coffee production on Dominica was accompanied by some level of deforestation, some of the crucial problems of soil cohesion were mitigated by the focus on coffee. Unlike sugar, coffee trees have roots that can extend up to three metres into the soil, to some degree binding the soil in place of the trees that previously occupied the area. ${ }^{21}$ Such is the strength of coffee roots that the tree is considerably hardier in the face of hurricane winds. On a tour of Jamaica in 1837, James Thome and Joseph Kimball noted with surprise that following the hurricane

\footnotetext{
20 Joseph Sturge, The West Indies in 1837, p.96.

${ }^{21}$ Bruce Schaffer and Peter C. Andersen, Handbook of Environmental Physiology of Fruit Crops (CRC Press, 1994), p. 103.
} 
that hit the island in 1812 , coffee production increased whilst sugar production decreased as the former did not suffer from the 'effects of a storm'.22

Arguably, it is in this context that we can understand the absence of landslips in the aftermath of the 1834 Dominican hurricane. For lack of scientific records, it is true that there is no empirical measure by which to compare the relative strengths of the Barbadian and Dominican hurricanes. However, a comparative similarity between the two events is the level of destruction wrought on the plantation and public buildings. In both cases eyewitness accounts relate that public buildings, private property and the plantations were completely destroyed. On Dominica a reverend called George Clarke relayed to London that there had been near total destruction of 'dwellings, negro huts [and] buildings' (the distinction between these three is testament to the power of the hurricane as it shows that stone buildings, both single level and multilevel, along with simple huts were all knocked down). ${ }^{23}$ It was also said that the hurricane that hit Dominica was strong enough to drive entire villages into the sea. ${ }^{24}$

The other great danger brought by a hurricane besides the building-flattening winds was the level of rainfall. Again, it is impossible to make an empirical comparison between levels in 1831 and 1834, but eyewitness accounts in 1834 show that there was certainly no shortage of rain. A Mr L.A. Loubiure relates that the estate of a $\mathrm{Mr}$ Courche was entirely washed away by a river swollen by rains. ${ }^{25}$ Indeed, the September $27^{\text {th }}$ issue of the Dominica Colonist reflected on the fact that in the weeks prior to the hurricane the island had been subject to frequent bouts of heavy rain.

\footnotetext{
22 James Armstrong, Joseph Horace Kimball, Emancipation in the West Indies: A six months' tour in Antigua, Barbadoes, and Jamaica in the year 1837 (Philadelphia: the American Anti-Slavery Society, 1838), pp.119-120.

${ }^{23}$ London, The National Archives, $\mathrm{T} 1 / 4397$, Extract of a letter sent by Rev George Clarke to (recipient not given), September 20, 1834.

${ }^{24}$ London, The National Archives, CO 71/78 (Dominica) Correspondence, Original-Secretary of State: Despatches; Offices and Individuals, J. Colquhoun to Spring Rice, November 12, 1834.

${ }^{25}$ TNA, T1/4397, L.A. Loubiure to M.L. Welch, Dominica, October 1, 1834.
}$$
* *
$$ 
Even if the hurricane itself brought little rain (though the aforementioned swelling of rivers would suggest otherwise), it is clear that the ground of the island was far from dry. ${ }^{26}$ Where we are therefore able to see some similarities in the strengths of the hurricanes in 1831 and 1834, there are also some important differences that strengthen the argument for sugar plantations as a factor both exacerbating vulnerability to hurricanes and generating epiphenomenal hazards.

Though as mentioned Dominica's central cash crop was coffee, the island did still have sugar plantations. The question is then why is there no record of significant landslips or otherwise significant movements in the soil surface? The answer arguably lies in the level of forest still present in Dominica in this period. In an important contrast to Barbados and the scale of its sugar plantations, J. Colquhoun makes mention of the fact that on Dominica to some degree it is the plantations themselves that are marginalised on the land. Coffee plantations were found in rocky ravines where importantly they also survived the hurricane. ${ }^{27}$ Colquhoun mentions that throughout Dominica there are many patches of 'uncultivatable woodland', something which stands in direct contrast to Barbados. ${ }^{28}$ Barbados effectively resembled one single 'vast sugar plantation'.$^{29}$ Dominica was always the most forested of the islands under British Caribbean control and those visiting it often commented on the density of its tree cover and vegetation. ${ }^{30}$ In $A$ Winter in the West Indies Joseph Gurney describes Dominica as a 'moist island... of luxuriant fertility; and nine tenths

\footnotetext{
${ }^{26}$ The Dominica Colonist, September 27, 1834.

${ }^{27}$ TNA, T1/4397, Colquhoun letter addressed to St. James's Place, April 7, 1835. ${ }^{28} \mathrm{Ibid}$.

29 B. W. Higman, Slave Populations of the British Caribbean, 1807-1834 (Kingston: University of the West Indies Press, 1995), p. 52.

30 Andreas Malm, 'The Final Conquest: Hurricane Maria as the latest battle in a 500 year war', Jacobin, <https://www.jacobinmag.com/2017/o9/hurricane-maria-dominica-climate-change>, [01/04/18].
} 
of the soil, productive as it is by nature, are wholly unoccupied - in a state of absolute wilderness' ${ }^{31}$

Consequently, unlike in Barbados in 1831 where the evidence of severe changes in the soil are clear from The Account, it is notable that nothing of a comparable nature appears in the reports coming from Dominica in 1834. What makes this more striking is that unlike in 1831 where there is only one single detailed eyewitness record, The Account, in the case of 1834 there are multiple assessments of the damage from different planters that were sent to London as evidence to attempt to boost the chance of securing Parliamentary assistance for the island. ${ }^{32}$

It is clear that to some degree the heavy deforestation wrought on the Caribbean by plantation agriculture exacerbated the potential of hurricanes to cause epiphenomenal hazards such as landslips that, particularly in the case of Barbados in 1831, lead to greater economic, environmental and human losses. Planters on Dominica did not put forward an estimate of the damage done by the hurricane for not wanting to intrude upon the valuable time of His Majesty's ministers. ${ }^{33}$ This is notable because planters submitted estimates of losses with regularity after nearly every nature-induced disaster. Often they tried to overestimate their losses so much so that grants of Parliamentary money had been refused to colonies previously when it was felt they had purposely inflated their losses. ${ }^{34}$ In this context, one could argue then because they did not submit estimates, losses on Dominica had not been that great and they were in fact waiting to see if Parliament offered them any money.

\footnotetext{
31 Joseph John Gurney, A winter in the West Indies, described in familiar letters to Henry Clay of Kentucky (London: J. Murray, 1840), p.72.

32 TNA, T1/4397, Letter written by Colquhoun sent to Rice compiles evidence of losses given by Dominican planters, November 13, 1834.

$33 \mathrm{TNA}, \mathrm{T} 1 / 4397$, Extract of letter from Rosalie Estate contained within Laidlaw to Gregg, October 2, 1834.

34 Parliamentary Papers (1831), House of Commons [197], West Indies. Copies of despatches from Barbados, St Vincent and St Lucia, relating to the late hurricane in the West Indies, p.18, (Boson to Goderich, August 18. 1831)

**
} 
Indeed, on Dominica only 29 people died, nearly all of them enslaved peoples, exposed as they were to even greater vulnerability through lack of shelter. ${ }^{35}$ By contrast, planters on Barbados estimated they had sustained losses amounting to $£ 2,311,729$ and that 1787 people died as a result of the hurricane, the highest proportion of which were enslaved peoples. ${ }^{36}$ Colonial records do not provide the detail by which to establish a cause of death in many of these cases but the author of The Account makes it clear that without the natural shelter provided by forest cover many Barbadians had no recourse but to run to open ground and suffer through the night. In consequence of this many were killed by flying debris. ${ }^{37}$

As well as playing a role in increasing casualties, the plantation also played a role in increasing the time it took to rebuild from hurricane impacts. On Barbados and Dominica timber was the primary construction material. Yet, despite the expense and the 'precarious footing' on which it put them, the plantation made them both entirely reliant on imports. ${ }^{38}$ The scale of deforestation on Barbados in particular had made it acutely reliant on imports. However, even on Dominica where deforestation was not as an endemic as it was on Barbados the plantation still prefigured the need to import timber. Visiting the island in 1837 Henry Sturge noted that 'the island imports great quantities of timber, and numbers of cattle and horses, though valuable trees grow on every estate... if it be asked, why man does not put forth his hand and gather the good things which nature provides with such spontaneous bounty, the reply is, that there is no surplus labor to devote to such minor matters; the sugar and

35 London, The National Archives, CO 71/78 (Dominica) Correspondence, Original-Secretary of State: Despatches; Offices and Individuals, J. Colquhuon, colonial agent to Earl of Aberdeen, October 1, 1834.

36 London, The National Archives, $\mathrm{CO} 31 / 51$ (Barbados) Sessional Papers. Assembly, December 20, 1831.

${ }^{37}$ Editor of the 'West Indian', p. 51-52.

38 Richard Grove, 'The British Empire and the Origins of Forest Conservation in the Eastern Caribbean 1700-1800', p.164.

$$
\text { ** }
$$


coffee cultivation absorb all the resources of the island'. ${ }^{39}$ Even when the resources were there, the requirements of generating profit re-directed energies. In effect, development of any kind was held back by plantation agriculture.

The plantation also marginalised the space and energy directed towards growing subsistence crops, while the long-range effects of deforestation also played a role in the need to import food. In the case of Barbados, the planters were largely reliant on rations of guinea corn to feed the enslaved peoples. ${ }^{40}$ Sourcing the majority of the food for such a large proportion of the island's population from a single source was a precarious arrangement in itself, but guinea corn brought its own issues that only compounded this vulnerability. Guinea corn was, in comparison to root vegetables, easily swept away during hurricanes. Indeed, in the wake of the 1831 hurricane, nearly all the fields of guinea corn were entirely destroyed. ${ }^{41}$ Starvation was only averted in 1831 through the import of American provisions. ${ }^{42}$

On all British colonies the enslaved population were given small allotments, and in a desire for economic agency most of what was grown on this land was sold as a cash crop for the export market. ${ }^{43}$ These plots became the site of frequent conflicts between planters and the enslaved over what they should plant. Enslaved peoples preferred to plant crops that would fetch higher prices at market such as plantains and other above-ground crops at risk of wind damage instead of deep root tubers such as yams. ${ }^{44}$ The scarcity of food in the aftermath of hurricanes certainly had a corrosive effect on the relations between planters and the enslaved. In 1831, enslaved

\footnotetext{
39 Joseph Sturge, The West Indies in 1837, p.98.

40 Kenneth F. Kiple, The Caribbean Slave: A Biological History (Cambridge University Press, 2002), p. 69.

${ }^{41}$ Editor of the 'West Indian', p. 103.

42 TNA, T1/4397, Lyon to Goderich, April 17, 1832

43 B.W. Higman, Slave Populations of the British Caribbean, 1807-1834, p. 207; Sylvia Winter, 'Novel and History, Plot and Plantation', Savacou, 5 (1970), pp.95-102

${ }^{44}$ Kenneth F. Kiple, The Caribbean Slave: A Biological History, p. 67-68.$$
\text { ** }
$$ 
peoples were punished and two shot when they were found by colonial authorities to be stockpiling the remnants of the guinea corn. Though it was not the site of violence after the hurricane of 1834 , a similar lack of subsistence crops forced planters on Dominica to have to import food to avert starvation. ${ }^{45}$

Through this comparison of these hurricane impacts there can be little doubt that the plantation played a significant role in increasing the vulnerability of the British Caribbean colonies in the early nineteenth century. In the case of Barbados in 1831 we can see that deforestation had serious implications for the cohesion of the island's soils. Landslips and exposure posed serious threats to the island's inhabitants where they did not to Dominica's in 1834. That said, even when the plantation did not increase the risk of epiphenomenal hazards the fact that Dominica, like Barbados, was reliant on importing food to avert starvation and timber to begin rebuilding shows the role it had in prolonging the recovery process.

Despite all of its attendant vulnerabilities, the plantation remained the centre of British Caribbean society into the late nineteenth century. The fact that the British vision for the region developed so little meant that the plantation continually exposed the region's inhabitants to increased risk. A hurricane in 1898 that hit Barbados and St. Vincent caused landslips that rendered many homeless and necessitated the rapid importation of provisions and timber. ${ }^{46}$ This system, as unsustainable and ill-suited to the region's environment as it was, remained because it primarily benefitted a select group of people who were far removed from its consequences. Such a conclusion should cause us to reflect on present day developments in the Caribbean. The majority of the islands previously colonised by the British source the majority of their

45 TNA, T1/4397, Extract of a letter sent by Rev George Clarke to (recipient not given), September 2O, 1834.

46 Parliamentary Papers (1898), House of Commons [C.9205], West Indies. Correspondence relating to the hurricane on $10^{\text {th }}-12^{\text {th }}, 1898$, and the relief of the distress caused thereby, p.2, (Governor Moloney to Secretary of State, September 15, 1898). 
revenues from tourism. ${ }^{47}$ This is an industry that has been primarily built by investors and other actors of global capital, who are removed from the deleterious effects it is continuing to have on the region's natural environments. Furthermore, a desire to meet debt obligations through the continued expansion of this industry is deprioritising designing policies to make these islands more resilient to natural hazards. ${ }^{48}$ Historical research on the disastrous effects the relentless drive for profit has had on the region should encourage those making contemporary policy decisions to consider what the acceptable limits to development are. ${ }^{49}$

\section{References}

Armstrong, J and Kimball JH 1838, Emancipation in the West Indies: A six months' tour in Antigua, Barbadoes, and Jamaica in the year 1837, The American Anti-Slavery Society, Philadelphia.

Bankoff, G 2004, 'Time is of the Essence: Disasters, Vulnerability and History', International Journal of Mass Emergencies and Disasters, vol. 22, no. 3, pp. 23-42.

Bishop, ML and Payne, A 2012, 'Climate Change and the Future of Caribbean Development', The Journal of Development Studies, vol. 48, no. 10, pp. 1536-53.

Funnell, D 2006, 'The British Empire and the origins of forest conservation in the Eastern Caribbean 1700-1800' in Anderson, Robert S, Grove, Richard and Hiebert, Karis (eds.), Islands, forests and gardens in the caribbean: conservation and conflict in environmental history, Macmillan Caribbean, London, pp. 132-173.

Gurney, JJ 1840, A winter in the West Indies, described in familiar letters to Henry Clay of Kentucky, J Murray, London.

Higman, BW 1995, Slave Populations of the British Caribbean, 1807-1834, University of the

\footnotetext{
47 Matthew Louis Bishop and Anthony Payne, 'Climate Change and the Future of Caribbean Development', The Journal of Development Studies, 48.10 (2012), 1536-53 <https://doi.org/10.1080/00220388.2012.693166>.

$48 \mathrm{lbid}$, p. 1549.

49 Professor Robin Mahon, "These Fields and Hills beyond recall": Barbados and Environmental Sustainability', 11/10/2016, Youtube, <https://www.youtube.com/watch?v=Y_KPo2jhtTY>, [22/05/2018].
} 
West Indies Press, Kingston.

Hughes, G 1750, The Natural History of Barbados In Ten Books, printed for the author, London.

Kiple, KF 2002, The Caribbean Slave: A Biological History, Cambridge University Press, Cambridge.

Madden RR, 1835, A Twelvemonth's Residence in the West Indies, during the Transition from Slavery to Apprenticeship; with Incidental Notice of the State of Society, Prospects, and Natural Resources of Jamaica and Other Islands, Carey, Lea and Blanchard, Philadelphia.

Mahon, R 2016, “These Fields and Hills beyond recall”: Barbados and Environmental Sustainability', 11/10/2016, Youtube, , [22/05/2018].

Mulcahy, M 2006, Hurricanes and Society in the British Greater Caribbean, 1624-1783, John Hopkins University Press, Baltimore.

Richardson BC 1992, The Caribbean in the Wider World, 1492-1992: A Regional Geography, Cambridge University Press, Cambridge.

Schafer, B and Andersen PC 1994, Bruce Schaffer and Peter C. Andersen, Handbook of Environmental Physiology of Fruit Crops, CRC Press, Boca Raton, Florida.

Schomburgk, RH 1848, The History of Barbados: Comprising a Geographical and Statistical Description of the Island, a Sketch of the Historical Events Since the Settlement, and an Account of Its Geology and Natural Productions, Longman, Brown, Green and Longmans, London.

Schwartz, S 2015, Sea of Storms: A History of Hurricanes in the Greater Caribbean from Columbus to Katrina, Princeton University Press, Princeton.

Smith, SD 2012, 'Storm Hazard and Slavery: The Impact of the 1831 Great Caribbean Hurricane on St Vincent', Environment and History, vol. 18, no. 1, p. 100.

Sturge, J 1838, The West Indies in 1837: being the journal of a visit to Antigua, Monsterrat, Dominica, St. Lucia, Barbadoes, and Jamaica; undertaken for the purpose of ascertaining the actual condition of the negro population of those islands, Hamilton, Adams and co., London.

'United Nations International Strategy for Disaster Reduction' 2009, UNISDR terminology on disaster risk reduction, Geneva. 
Hurricane vulnerability in the nineteenth-century British Caribbean | 42

Watts, D 1990, The West Indies: Patterns of Development, Culture and Environmental Change Since 1492, Cambridge University Press, Cambridge. 